8. Hladushniak, O. K. (2015). Tekhnolohichne obladnannia konseronykh zavodiv. Kherson: Hrin D. S., 348.

9. Zahorulko, A. M., Zahorulko, O. Ye. (2016). Pat. No. 108041 UA Hnuchkyi plivkovyi rezystyonyi elektronahrivach oyprominiuiuchoho typu. MPK G05D 23/19, B01D 1/22, H05B 3/36. No. u201600827; declareted: 02.20.2016; published: 24.06.2016 Bul. No. 12, 4

10. Kremniiorhanichna ridyna PFMS-4. Available at: http://www. chemproduct.ru/shop/goods/598/

Zagorulko Aleksey, PhD, Associate Professor, Department of Processes, Devices and Automation of Food Production, Kharkiv State University of Food Technology and Trade, Ukraine, ORCID: http:// orcid.org/0000-0003-1186-3832,e-mail: zagorulko@hduht.edu.ua
Zahorulko Andreii, PhD, Associate Professor, Department of Processes, Devices and Automation of Food Production, Kharkiv State University of Food Technology and Trade, Ukraine, ORCID: http:// orcid.org/0000-0001-7768-6571,e-mail: zagorulkoAN@hduht.edu.ua

Liashenko Bogdan, PhD, Associate Professor, Department of Processes, Devices and Automation of Food Production, Kharkiv State University of Food Technology and Trade, Ukraine, ORCID: http:// orcid.org/0000-0001-7228-8814

Gordienko Iryna, Postgraduate Student, Department of Processes, Devices and Automation of Food Production, Kharkiv State University of Food Technology and Trade, Ukraine, ORCID: http:// orcid.org/0000-0002-2274-7565

\section{Sytnik N., Mazaeva V., Bilous O., Bukhkalo S., Glukhykh V., Sabadosh G., Natarov V., Yarmysh N., Kravchenko T., Zakharkiv $\mathbf{S}$.}

\title{
RESEARCH OF OXIDATIVE STABILITY OF VEGETABLE OILS FOR USE IN SPORT NUTRITION
}

Об’єктом дослідження є соняшникова, соняшникова високоолеїнова та ріпакова олї, які є важливими у виробнищтві продуктів харчування для людей з підвищеними фізичними навантаженнями. Такі продукти мають бути збалансовані за компонентним складом та збагачені біологічно активними речовинами, вітамінами, антиоксидантами. Олї та жири використовують як важливий компонент спортивного харчування. Розповсюдженою олією є соняшникова олія, яка забезпечує раціон лінолевою кислотою, а також ріпакова олія, яка збагачує продукти ліноленовою кислотою. Одним з найбільш проблемних місиь використання олій є окиснювальне псування, оскільки це призводить до утворення небезпечних для здоров'я сполук. В ході дослідження використовувалися метод активного кисню та прилад Охіtеst (Iталія). Перший метод дозволяє безпосередньо очінювати вміст продуктів окиснення в олії через значення пероксидного числа, другий метод дозволяє вимірювати витрату кисню під час процесів окиснення в оліі.

Проведено дослідження окиснювальної стабільності олї соняиникової методом активного кисню та методом окиснення з використанням приладу Oxitest за температури $110{ }^{\circ} \mathrm{C}$. Встановлено, що періоди індукщї, визначені двома методами, є близькими (2 год. 40 хв. та 2 год. 43 хв., відповідно). Встановлено закономірність зниження періоду індукиї олії соняшникової під час підвищення температури методом окиснення на приладi Oxitest. Використано температури 90, 100 та $110{ }^{\circ} \mathrm{C}$. Виконано порівняльне дослідження окиснювальної стабільності соняшникової, соняшникової високоолеїнової та ріпакової олій. На підставі одержаних даних наведено порівняльну характеристику стійкості дослідних олій до окиснення та надано рекомендащї для їх використання у спортивному харчуванні. Одержані дані дозволять оцінювати вплив кожної з дослідних олій на строк придатності олієвмісного продукту.

Ключові слова: спортивне харчування, олія соняшникова, олія ріпакова, окиснювальна стабільність, період індукиї.

\section{Introduction}

Current nutritional requirements require the consumption of polyunsaturated fatty acids, essential amino acids and minerals in sufficient quantities. But usually modern nutrition does not fully satisfy the need for such important components [1,2]
A particularly acute issue of good nutrition is relatively certain categories of the population, in particular, people who engage in sports activities. Preparation for the competition, daily training, high psychological endurance require special nutrition, which will contribute to high endurance and quick recovery [3-5]. In order to meet the needs of the body of a person involved in sports, special 
products are currently being developed, for example, highprotein products, confectionery, beverages, etc. [6-8]. At the same time, one of the most important components of such products is oils and fats, which provide the necessary balance of fatty acids valuable for metabolism.

Among used oils, sunflower and corn are a valuable source of linoleic acid (9, 12 octadecadienoic, group $\omega-6)$; soybean, rapeseed, flaxseed and cameline $\alpha$-linolenic (group $\omega-3)$. These acids are not synthesized in the human body and can only get into it as part of food products. They take part in the synthesis of hormones and in the metabolism in cells, in the creation of cell membranes. So, the study of these oils from the point of view of their use for creating sports nutrition is of significant interest [9].

The high oleic sunflower oil as a component of many types of food products is also attracting more and more attention. High oleic oils and oils are characterized by a high content of monounsaturated fatty acids. This is an advantage in terms of food hygiene, since it means a lower content of saturated acids, the absence of trans isomers of fatty acids, and also provides increased resistance to oxidation. The latter property is undeniably important in the production and use of all fat-containing products due to the tendency of oils and fats to oxidative damage $[10,11]$.

Oxidative processes lead to the formation of substances harmful to the human body, which leads to an increasing interest of researchers in studying the laws of oxidation of oils and fats with various fatty acid compositions and the search for new effective and environmental antioxidants [12].

Various methods are used to determine oxidative stability, among which the barometric method for determining the oxidation stability of oils, fats, and fat-containing products using the Oxitest device (Italy) is distinguished. In this case, increased temperature and pressure are used. This method reliably allows to determine the resistance of the sample to the action of oxygen, which allows to draw conclusions about the freshness, effectiveness of antioxidants and shelf life of products [12].

Therefore, it is relevant to study the oxidative stability of vegetable oils, which are promising components of various types of food products, including sports.

Thus, the object of research is sunflower, high oleic sunflower and rapeseed oil, which are important in the production of food for people with increased physical activity.

And the aim of research is a comparative study of the oxidative stability of vegetable oils (sunflower, high oleic sunflower and rapeseed) by various methods (active oxygen method and using the Oxitest device).

\section{Methods of research}

2.1. The investigated materials and equipment used in the experiment. The following reagents and materials were used in this study:

- refined deodorized rapeseed oil in accordance with DSTU 8175:2015;

- high oleic refined deodorized sunflower oil in accordance with current regulatory documents;

- refined deodorized sunflower oil in accordance with DSTU 4492:2017;

- gas cylinder with oxygen purity not lower than $99.95 \%$ according to the current regulatory documentation;

- rectified ethyl alcohol according to DSTU 4221:2003;

- distilled water current regulatory documentation;
- potassium iodide qualification «especially pure»according to the current regulatory documentation;

- soluble starch according to the current regulatory

documentation;

- sodium thiosulfate according to the current regulatory documentation;

- acetic acid according to the current regulatory documentation;

- chloroform according to the current regulatory documentation;

- Oxitest device (Italy).

2.2. Method for determining the oxidative stability of sunflower oil by the method of active oxygen. The oxidative stability of sunflower oil samples is determined by the accelerated method of active oxygen, which provides for the determination of the induction period for the change in the peroxide number during oil exposure at a given temperature. $10 \mathrm{~g}$ of an oil sample was introduced into the glass containers, placed in an oven heated to a predetermined temperature. To determine the peroxide value from the oven at regular intervals, the corresponding bottle was selected. The value of the induction period of sunflower oil was determined graphically from the growth curves of peroxide numbers by the tangent method.

The peroxide value is determined by the standard method according to DSTU 4350:2004.

2.3. Method for determination of oxidative stability of oil samples using the Oxitest instrument. The Oxitest device (Fig. 1) allows to assess the resistance degree of various types of products (oils, fats, flour, cheeses, milk powder, meat products, sauces, seeds and other fat-containing products) to oxidation. In this case, the change in pressure is controlled due to oxygen absorption during the oxidation of the prototype in two autonomous thermostatic chambers.

The chambers are filled with a prototype and carefully closed, after which heating of the chamber to a predetermined temperature begins, then oxygen is supplied to the chamber. After the set pressure is set to 6 bar $(0.6 \mathrm{MPa})$, the oxygen supply is pricked up and the reaction time measurement is turned on.

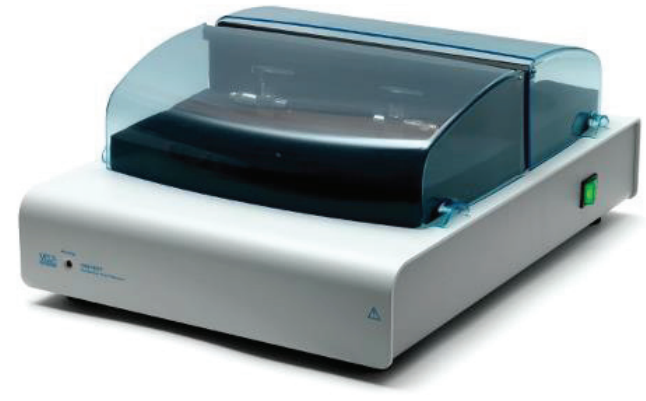

Fig. 1. Oxitest device

The study of oil oxidation is carried out according to the nature of the curve, which is automatically based on the graphical dependence of pressure on reaction time. An example of a graphical dependence is shown in Fig. 2.

At the end of the test, the user can use two equivalent methods for calculating the induction period: the graphical method and the least squares method. 


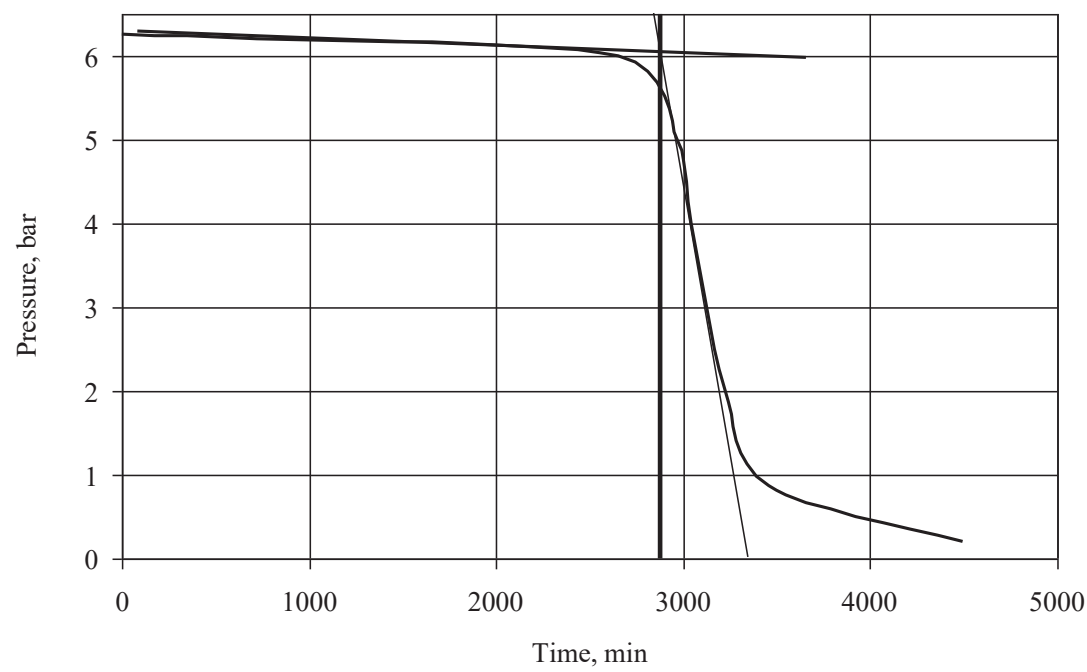

Fig. 2. Graphical dependence of pressure on reaction time for calculating the induction period when oxygen begins to be actively spent on oil oxidation processes, while the pressure in the chamber decreases sharply. After the end of this process, the pressure in the chamber remains constant and does not exceed 1.58 bar $(0.158 \mathrm{MPa})$. When processing the graphic dependence, the induction period is obtained 2 hours 43 minutes.

In parallel, a study is conducted to determine the period of induction of sunflower oil by the method of active oxygen, after changing the values of the peroxide value under conditions of oil soaking at a temperature of $110{ }^{\circ} \mathrm{C}$.

The results of determining the induction period by the method of active oxygen are shown in Fig. 4, as the dependence of the peroxide number on the oxidation time.

The graphical method allows to automatically build two tangent lines - the pressure curve before and after bending and get the point of intersection. From this intersection point, a perpendicular to the abscissa is drawn. The numerical value on the abscissa axis, on which the perpendicular is dropped, is the numerical value of the induction period.

In the case of the least squares calculation, the graphical dependence first displays four vertical lines that define two groups of curve points, are reduced to two lines. The intersection point of these two lines gives the value of the induction period of the sample.

In the work, the induction period is calculated using the graphical method. The error in calculating the experimental data obtained using the Oxitest instrument does not exceed $3 \%$ [12].

\section{Research results and discussion}

For a comparative analysis of the determination of the induction period by various methods, the active oxygen method and the Oxitest device were used. Refined deodorized sunflower oil was used as research oil. The study temperature was $110{ }^{\circ} \mathrm{C}$.

Fig. 3 shows the dependence of the oxidation time on the oxygen pressure in the thermostatic chamber of the Oxitest device.

As can be seen from Fig. 3, the oxygen pressure in the chamber for a certain time decreases rather slowly, which corresponds to the diffusion of oxygen from the contact surface of the oil with oxygen. Thus, in this period of time, the oil remains stable until oxidative processes. Then there comes a moment of a sharp change in pressure,

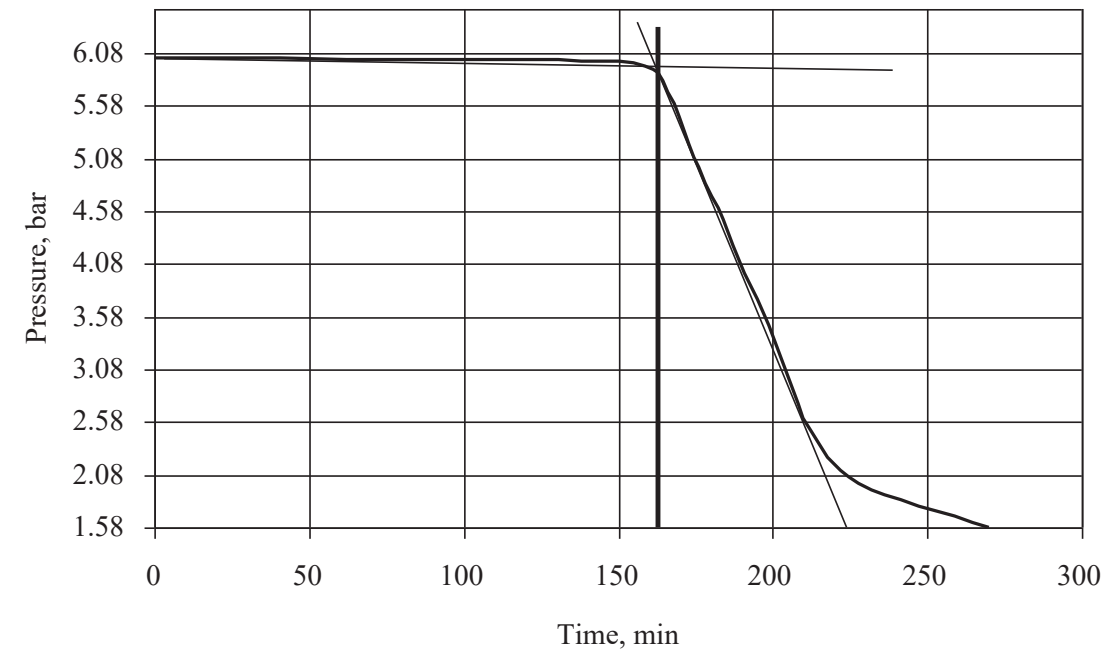

Fig. 3. The dependence of the oxidation time on the oxygen pressure in a thermostatic chamber

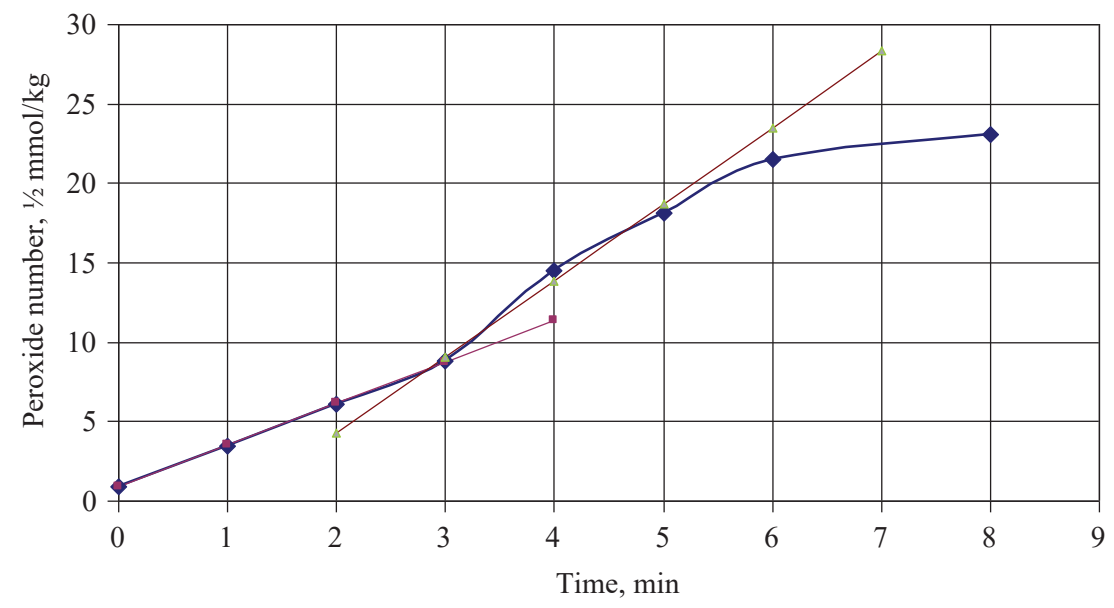

Fig. 4. The dependence of the peroxide number of sunflower oil on the oxidation time 
Thus, the oxidative stability of sunflower oil at a temperature of $110^{\circ} \mathrm{C}$ is determined by two different methods. Despite the difference in the principles of the methods, the values of the induction periods are determined to be close. The method of active oxygen allows to determine the induction period through a direct indicator of oxidative damage - the peroxide number, which is reliably characterizes the accumulation of peroxide compounds in the prototype. But this method is time-consuming, requires the use of special reagents and materials, as well as high precision laboratory tests. The Oxitest method is an innovative modern tool for studying the oxidative stability of various foods. It does not require high operator qualifications, additional materials and allows to reliably determine the induction period through the oxygen consumption rate of the prototype. So, the Oxitest device has undeniable advantages over the active oxygen method, since it automatically determines the induction period and reduces the influence of the human factor on the final result.

A study was made of the effect of temperature on the induction period of refined deodorized sunflower oil on an Oxitest device at the temperatures of 90,100 and $110{ }^{\circ} \mathrm{C}$. The duration of the study with a decrease in temperature increases from 5 hours and 60 minutes at a temperature of $110{ }^{\circ} \mathrm{C}$ until 22 hours 50 minutes at a temperature of $90{ }^{\circ} \mathrm{C}$. The induction period of sunflower oil with different temperatures is shown in Fig. 5.

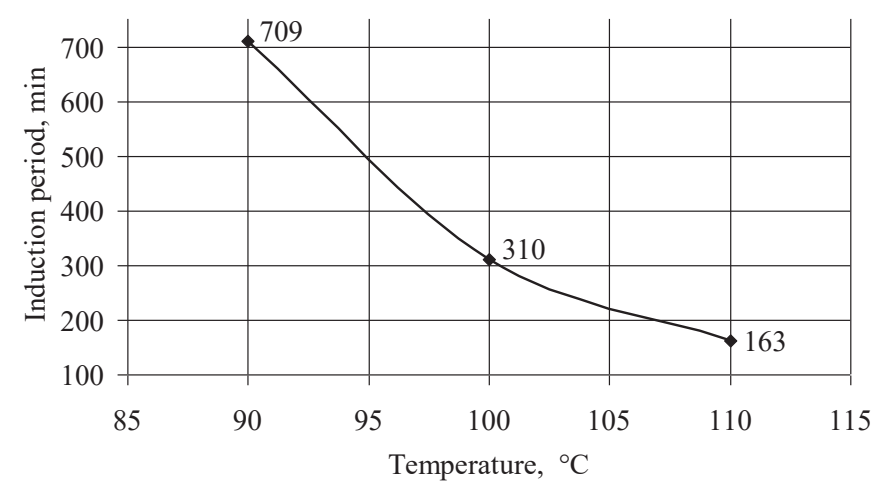

Fig. 5. The induction period of sunflower oil with different temperatures (709 minutes equal to 11 hours 49 minutes, 310 minutes equal to 5 hours 10 minutes, 163 minutes equal to 2 hours 43 minutes)

As can be seen from the presented data (Fig. 5), with an increase in temperature from 90 to $100^{\circ} \mathrm{C}$, the induction period decreases by 2.3 times, with an increase in temperature from 100 to $110{ }^{\circ} \mathrm{C}$, the induction period decreases by 1.9 times. Thus, a temperature increase of $10{ }^{\circ} \mathrm{C}$ reduces the induction period by about half.

For a quick assessment of the oxidative stability of a sample, it is advisable to use a temperature of $100{ }^{\circ} \mathrm{C}$ and higher.

The oxidative stability of sunflower, high oleic sunflower and rapeseed oils using the Oxitest device are compared at a temperature of $100{ }^{\circ} \mathrm{C}$. Table 1 shows the results obtained for periods of induction of research oils.

As can be seen from the data in Table 1, behind the Oxitest device, the smallest induction period has sunflower oil, and the highest sunflower oil is high oleic. Rapeseed oil has an induction period of 1.8 times more than sunflower oil.
Table 1

The values of the induction periods of research oils

\begin{tabular}{|l|c|}
\hline \multicolumn{1}{|c|}{ Sample name } & Induction periods \\
\hline Sunflower oil & 5 hours 10 minutes \\
\hline High oleic sunflower oil & 11 hours 50 minutes \\
\hline Rapeseed oil & 9 hours 23 minutes \\
\hline
\end{tabular}

Based on the data obtained on the study of the oxidative stability of types of oils that are important for use in sports practice, it is found that the highest oxidative stability is in the case of high oleic sunflower oil. This is due to the increased content of monounsaturated acids in comparison with other experimental samples of oils. The obtained induction periods allow to evaluate the oxidative behavior of oils in the composition of food products and make decisions on the component composition of oils in the product.

It should be noted that the method of the Oxitest device relative to the method of active oxygen makes it possible to work not only with fats and oils in pure form, but with fat-containing products, without isolating the fat phase, reduces the complexity of the analysis. In addition, this eliminates the distortion of the results for additional operations with the prototype, which can lead to a change in the oxidative state. By extracting fat in products such as seeds and nuts, not all natural inhibitors found in fruits and seeds can be removed, and thus the result of determining the induction period can also be distorted. Cosmetics and food products that contain water and fatty components, such as cheeses, cosmetic creams, lipsticks and other products, can also be used in their original form, without removing fat components from them. In such cases, the experiment at elevated pressure in the measuring chamber of the device will ensure the stability of the water contained in the object (preserving it in the liquid phase), even at temperatures above $100{ }^{\circ} \mathrm{C}$.

This makes it possible, in addition to pre-setting the oxidative stability of oils, to further determine the oxidative stability of the finished product for sports purposes. The data obtained using the Oxitest device makes it possible to reliably and efficiently select the optimal composition of a multi-component product in order to ensure the required shelf life.

\section{Conclusions}

A comparative analysis of the induction period of sunflower oil is made by the method of active oxygen and on the device Oxitest. It is found that the values of the induction periods are close ( 2 hours 40 minutes and 2 hours 43 minutes). But at the same time, the Oxitest device has several advantages along with the active oxygen method.

Using the Oxitest instrument, the regularity of the change in the oxidative stability of sunflower oil with temperature is studied. With an increase in temperature for every $10{ }^{\circ} \mathrm{C}$, the period of oil induction is almost halved.

The oxidative stability of sunflower, high oleic sunflower, rapeseed oils are compared using the Oxitest method. The periods of oil induction are determined, among which the highest oxidative stability is found in high oleic sunflower 
oil. Rapeseed oil has an induction period of 1.8 times more than sunflower oil.

The obtained results are important in the production of balanced multi-component products for sports nutrition, since the component determines the shelf life of the product, mainly oils and fats. Moreover, they are the most important functional part of many types of sport products.

\section{References}

1. Subbotina, M. (2009). Faktory, opredeliaiuschie biologicheskuiu cennost rastitelnykh masel i zhirov. Vestnik KuzGTU, 2, 86-90.

2. Cencic, A., Chingwaru, W. (2010). The Role of Functional Foods, Nutraceuticals, and Food Supplements in Intestinal Health. Nutrients, 2 (6), 611-625. doi: http://doi.org/10.3390/nu2060611

3. Holway, F. E., Spriet, L. L. (2011). Sport-specific nutrition: Practical strategies for team sports. Journal of Sports Sciences, 29 (1) 115-125. doi: http://doi.org/10.1080/02640414.2011.605459

4. Rylova, N., Khafizova, G. (2012). Aktualnye problemy pitaniia iunykh sportsmenov. Prakticheskaia medicina, 7 (62), 71-74.

5. Jeukendrup, A., Cronin, L. (2011). Nutrition and elite young athletes. Medicine and sport science, 56, 47-58. doi: http:// doi.org/10.1159/000320630

6. Aranson, M., Portugalov, S. (2011). Sportivnoe pitanie: sostoianie voprosa i aktualnye problemy. Vestnik sportiznoi nauki, 1,33-37.

7. Schneider, M., Benjamin, H. (2011). Clinical report - sports drinks and energy drinks for children and adolescents: are they appropriate? Pediatrics, 127 (6), 1182-1189. doi: http:// doi.org/10.1542/peds.2011-0965

8. Rajasekhar, K. (2018). Sports nutrition - a perspective. Advances in Nutrition \& Food Science, 3 (2), 1-4. doi: http://doi.org/ $10.33140 / \mathrm{anfs} / 03 / 02 / 00008$

9. Agzamova, L. (2010). Ispolzovanie kukuruznogo i rapsovogo masel v kachestve fritiura pri proizvodstve muchnogo konditerskogo izdeliia. Vestnik Kazanskogo tekhnologicheskogo universiteta, 11, 252-256.

10. Sultanovich, Iu. (2012). Vysokooleinovoe podsolnechnoe maslo osnova dlia fritiurnykh masel i zhirov. Pischevaia promyshlennost, 3, 22-24.

11. Rosa, F., Luca, I., Mario, T. (2018). Sunflower Oil Functional Properties for Specialty Food. Nutrition $\mathcal{E} F$ Food Science International Journal, 5 (4), 601-604. doi: http://doi.org/10.19080/ nfsij.2018.05.555668

12. Bilous, O., Demydov, I., Bukhkalo, S. (2015). Developing the complex antioxidant from walnut leafs and calendula extracts. Eastern-European Journal of Enterprise Technologies, 1 (6 (73)), 22-26. doi: http://doi.org/10.15587/1729-4061.2015.35995

Sytnik Natalia, PhD, Department of Studies of Technology for Processing Oils and Fats, Ukrainian Research Institute of Oils and Fats of National Academy of Agrarian Sciences of Ukraine, Kharkiv, Ukraine, e-mail: ntlsytnik@gmail.com, ORCID: http://orcid.org/ 0000-0002-3970-086X
Mazaeva Viktoria, PhD, Department of Studies of Technology for Processing Oils and Fats, Ukrainian Research Institute of Oils and Fats of National Academy of Agrarian Sciences of Ukraine, Kharkiv, Ukraine, e-mail: vika1988977@gmail.com, ORCID: http:// orcid.org/0000-0002-5560-9126

Bilous Olesia, PhD, Department of Physical Education, National Technical University «Kharkiv Polytechnic Institute», Ukraine, e-mail:fazia@ukr.net, ORCID: http://orcid.org/0000-0002-8262-2553

Bukhkalo Svitlana, PhD, Associate Professor, Senior Researcher Department of Integrated Technologies, Processes and Devices, $\mathrm{Na}$ tional Technical University «Kharkiv Polytechnic Institute», Ukraine, e-mail: bis.khr@gmail.com, ORCID: http://orcid.org/0000-00021389-6921

Glukhykh Valentyna, Department of Physical Rehabilitation, Sports Medicine, Physical Education and Health, Zaporizhzhia State Medical University, Ukraine, e-mail: valentina.gluhih20@gmail.com, ORCID: http://orcid.org/0000-0001-7034-1044

Sabadosh Ganna, PhD, Department of Technology and Organization Restaurant Business, Uzhhorod Institute of Trade and Economics of Kyiv National University of Trade and Economics, Ukraine, e-mail: aasaa30@ukr.net, ORCID: http://orcid.org/0000-00024749-5608

Natarov Vadym, Department of Physical Education, National Technical University «Kharkiv Polytechnic Institute», Ukraine, e-mail: natric.dima@gmail.com, ORCID: http://orcid.org/00000001-9242-4350

Yarmysh Natalia, Department of Physical Education, National Technical University «Kharkiv Polytechnic Institute», Ukraine, e-mail: mashenkakuznecova@gmail.com, ORCID: http://orcid.org/ 0000-0002-4450-8215

Kravchenko Tetiana, PhD, Department of Theory and Methods of Physical Education and Sports, State Higher Educational Institution «Pereiaslav-Khmelnytskyi Hryhorii Skovoroda State Pedagogical University», Ukraine, e-mail: kravchenko19tanya@gmail.com, ORCID: http://orcid.org/0000-0002-6041-3101

Zakharkiv Stepan, Postgraduate Student, Department of Theory and Methods of Physical Education and Sports, State Higher Educational Institution «Pereiaslav-Khmelnytskyi Hryhorii Skovoroda State Pedagogical University», Ukraine, e-mail: stepan72@ukr.net, ORCID: http://orcid.org/0000-0002-7964-4778 